\title{
A hereditaer nonpolyposus colorectalis carcinoma szindrómás betegek szürésének és szoros utánkövetésének fontossága egy családfa bemutatása kapcsán
}

\author{
Kóder Gergely dr. ${ }^{1}$ - Olasz Judit ${ }^{5}$ - Tóth László dr. ${ }^{2}$ \\ Urbancsek Hilda dr. ${ }^{3}$ - András Csilla dr. ${ }^{3}$ - Bubán Tamás dr. ${ }^{4}$ \\ Palatka Károly dr. ${ }^{4}$. Damjanovich László dr. ${ }^{1}$. Tanyi Miklós dr. ${ }^{1}$ \\ Debreceni Egyetem, Általános Orvostudományi Kar, Klinikai Központ, 'Sebészeti Klinika, \\ ${ }^{2}$ Pathologiai Intézet, ${ }^{3}$ Onkológiai Klinika, ${ }^{4}$ Belgyógyászati Klinika, Debrecen \\ ${ }^{5}$ Országos Onkológiai Intézet, Pathogenetikai Osztály, Budapest
}

\begin{abstract}
Bevezetés: A hereditaer nonpolyposus colorectalis carcinomára jellemző mutációk (HNPCC) autoszomális domináns öröklődésmenetet mutatnak. Leginkább vastagbéldaganatok kialakulásáért felelősek.

Célkitüzés: A HNPCC-szindrómás betegek szürésének és követésének fontosságát szeretnénk hangsúlyozni egy igazolt MMR-gén-mutációt hordozó betegünk jelenlegi és 10 évvel korábbi családfájának összehasonlításával. Betegek és módszer: Hazánkban előforduló, HNPCC-re gyanús családok kiszűrése érdekében alapos családi anamnézist veszünk fel. Amennyiben az immunhisztokémiai és mikroszatellitainstabilitás-vizsgálatok HNPCC-szindrómára utalnak, elvégezzük az MMR-gének szekvenálását.

Eredmények: Betegünknél egy, a hMSH2-gén 6. exon két bázispárt érintő deletiója (c.969-970delTC) igazolódott. Tízéves utánkövetés során betegünknél és rokonainál újabb, a HNPCC-re jellemző tumorok jelentek meg. Köpetkeztetés: A veszélyeztetett családtagok követése során a szekunder prevenció a jól együttmúködő betegeknél hatékony volt.
\end{abstract}

Orv Hetil. 2017; 158(30): 1182-1187.

Kulcsszavak: hereditaer nonpolyposus colorectalis carcinoma, Lynch, szekunder prevenció

Significance of the monitoring and screening for hereditary nonpolyposis colorectal carcinoma syndrome patients by presenting a case of a family tree

Introduction: Hereditary nonpolyposis colorectal carcinoma (HNPCC) is an autosomal dominant disease, which shows familial clustering.

Aim: We would like to emphasize the importance of monitoring the HNPCC syndrome patients by presenting a case of a proven MMR gene mutation carrier and her family tree encompassing 10 years.

Materials and method: To screen a suspected HNPCC Hungarian family member we are taking thorough family histories. If the diagnosis of HNPCC was further supported by immunohistology and the microsatellite status, sequencing of the MMR genes was carried out.

Results: A novel mutation in exon 6 of the hMSH2 gene leading to the deletion of two nucleotide pairs [c.969970delTC] was detected in our patient. During the 10-year follow-up period of our patient new HNPCC-associated tumors have developed in several family members.

Conslusion: Close surveillance of the patient and its family members at risk was effective, although it requires compliance from the subjects. 
Keywords: hereditary nonpolyposis colorectal carcinoma, Lynch, secunder prevention

Kóder G, Olasz J, Tóth L, Urbancsek H, András Cs, Bubán T, Palatka K, Damjanovich L, Tanyi M. [Significance of the monitoring and screening for hereditary nonpolyposis colorectal carcinoma syndrome patients by presenting a case of a family tree]. Orv Hetil. 2017; 158(30): 1182-1187.

(Beérkezett: 2017. május 8.; elfogadva: 2017. június 8.)

\begin{abstract}
Rövidítések
APC = adenomatosus polyposis coli gén, egy tumorszuppreszszor gén (suppressor gene) vagy antionkogén; DNS = dezoxiribonukleinsav, a sejt genetikai információt tároló molekulája; EPCAM = epithelial cellular adhesion molecule; HNPCC = hereditaer nonpolyposus colorectal carcinoma; $\mathrm{MMR}=($ mismatch repair) a DNS hibás bázispárosodását javító egyik rendszer; MSI = (microsatellite instability) mikroszatellita-instabilitás; MSI-H = magas fokú mikroszatellita-instabilitás; MSI-L = alacsony fokú mikroszatellita-instabilitás; MSS $=($ microsatellite stable) mikroszatellita stabil állapot; $\mathrm{UH}=$ ultrahangvizsgálat; PET-CT = pozitronemissziós tomográfia-komputertomográfia
\end{abstract}

\section{Genetikai háttér}

A vastagbélrák világszerte a második leggyakrabban előforduló daganatos megbetegedés. Az összes vastagbélrák közül a sporadikus megjelenésû́ rákok az esetek 70-80\%át teszik ki, míg a fennmaradó $20-30 \%$ jelenti a családi halmozódású eseteket, ezeknek körülbelül fele sorolható a családi rákszindrómák körébe $[1,2]$. Ilyen családi halmozódást mutat a hereditaer nonpolyposus colorectalis carcinoma (HNPCC) is, amely a vastagbéldaganatok 3-6\%-át teszi ki $[3,4]$. A betegségre jellemző MMRgén-mutációk autoszomális dominánsan öröklődnek, 80-85\%-os penetranciával. Jellemző a családi halmozódás mind az elsőfokú rokonok, mind egymást követő generációk között $[5,6]$. A vastagbélrák onkogenetikai szempontból alapvetóen két eltérő genetikai útvonalon keresztül alakul ki. Az első csoport kromoszomális instabilitással jár, amely fóképp az APC-gén funkcióvesztéséból indul ki $[1,7,8]$. A másik csoportra a kromoszomális stabilitás, valamint az úgynevezett mikroszatellitainstabilitás jellemzőo. Más néven ezt HNPCC-útvonalnak is nevezik [9]. A Mut-családba tartozó MMR-gének fehérjetermékei (hMLH1, hMLH3, hMSH2, hMSH3, hMSH6, hPMS1, hPMS2) felelősek a DNS-replikáció során a DNS-bázispárosodásban felhalmozódott hibák felismeréséért és javításáért, így a mikroszatellita-stabilitásért is [10-12]. Ha az MMR-rendszer hibásan múködik, akkor a mikroszatelliták másolása közben kialakult hibák átírásra kerülnek, így az ismétlődő szekvenciák száma növekszik vagy csökken. Ezt az állapotot nevezzük mikroszatellita-instabilitásnak (MSI). A tumorok MSIstátusza alapján megkülönböztetünk magas és alacsony instabilitású (high és low level instability - MSI-H,
MSI-L), továbbá mikroszatellita-stabil (microsatellite stable - MSS) fenotípust [11, 13]. A mikroszatellita-instabilitás kialakulásáért számos gén által kódolt fehérje funkcióváltozása vagy a fehérje mennyiségének változása felelős. Ilyen gének például: TGF- $\beta R I I B A X, t C F 4$, MSH3, MSH6, GF2R, TACSTD1. Ezeknek a géneknek a fehérjetermékei a sejtproliferációban, növekedéskontrollban és számos jelátviteli útvonalban játszanak fontos szerepet. Az MMR-gének hibái folytán kialakuló MSI tehát a jelátviteli útvonalak szabályozásának felborulásával egyaránt megváltoztatja a proliferációt, a differenciálódást, a sejt-sejt kapcsolatokat és az apoptózis normális múködését is [10, 13-15]. A HNPCC-szindróma kialakulásának hátterében az esetek több mint 90\%-ában az MLH1- és MSH2-gének mutációja áll, míg a maradék kevesebb, mint 10\%-ában MSH6-, PMS1- és PMS2-gének mutációi $[3,4,16]$. A HNPCC-szindróma kialakulásáért 3\%-ban az EPCAM-gén mutációja a felelős, amelynek következtében az MSH2-gén promóter szakaszának a hipermetilációja következik be, amely HNPCCszindrómához hasonló fenotípust idéz elő. Általánosságban elmondható, hogy MLH1- és MSH2-gének mutációja esetén a colorectalis daganatok kialakulásának legnagyobb az esélye. MSH6- vagy PMS2-gének mutációja esetén viszont nagyobb százalékban alakul ki endometriumcarcinoma, mint az MLH1- és MSH2-mutációt hordozók esetében [17].

\section{Klinikai jellemzők}

A HNPCC-szindrómára jellemző, hasonlóan, mint a sporadikus daganatok esetében, hogy itt is adenomacarcinoma átalakulás figyelhetô meg, de az adenomák kialakulásának valószínúsége nem nagyobb a populációs átlagnál. A HNPCC-szindrómás betegnél a már kialakult adenomatosus polipok carcinomává transzformálódása sokkal gyorsabban, akár egy-két év alatt lezajlik, így ezen betegek rendszeres, akár évente elvégzett kontrollkolonoszkópiája és szükség esetén polipectomiája nagy jelentőséggel bír [10-12]. Minden 35. új colorectalis daganatos megbetegedésre egy HNPCC-szindrómás jut [18, 19]. A HNPCC-re jellemző, hogy a daganatos megbetegedés korán, leginkább a negyvenes életkorban jelentkezik, az esetek $70 \%$-ában a jobb colonfél érintett, gyakoriak a szinkron és metakron tumorok, továbbá vastagbélen kívüli HNPCC-szindrómához asszociált daganatok, amelyek közül a leggyakoribb az endometriumcarcino- 
ma. Idesorolható a gyomor, ovarium, urether, vesekehely, epeúti, vékonybél, bőr sebaceous daganatai [20]. Igazolt patogén mutációt hordozó HNPCC-s betegek esetén 80-90\%-os valószínúséggel alakul ki életük során vastagbéldaganat, míg a nők körülbelül 30-60\%-ánál jön létre endometriumdaganat a mutáns MMR-géntől függően [21].

\section{A HNPCC-szindróma szürése és gondozása}

A Debreceni Egyetem Sebészeti Intézetében vastagbéldaganat mütéti ellátása céljából felvett betegeknél módosított Amszterdam és Bethesda Kritériumok felhasználásával elkészített kérdőívünket alkalmazzuk. A kérdőívet a vizsgálatot végző orvos tölti ki a beteggel történő személyes találkozás során. Ezen kérdőív segítségével szưrjük ki első körben a HNPCC-szindrómára gyanús eseteket. Az Amszterdam- és Bethesda-pozitív betegeknél ezek után a vastagbél preparátumaiból mintavétel történik immunhisztokémiai vizsgálat céljából. Formalinban fixált, paraffinba ágyazott vastagbél-carcinomás szöveteket használunk. Ennek segítségével mutathatjuk ki a beteg tumoros szövetének sejtmagjaiban az MMR-gének fehérjetermékeinek expresszióját vagy annak hiányát. Az MMR-immunhisztokémia előnyei: széles körben hozzáférhető, alkalmas az MMR-mutáció előszűrésére, a mutált génre utal, minden HNPCC-ajánlás javasolja. Emellett a mikroszatellita-instabilitás vizsgálatát a tumoros szövet és a perifériás vér fehérvérsejtjeiből izolált DNS felhasználásával végezzük. Amennyiben az immunhisztokémiai vizsgálat során valamely vizsgált MMR-gén expressziójának hiányát találjuk, továbbá, ha a mikroszatellita-instabilitás magas fokú, a beteg perifériás véréből elvégezhetjük az MMR-gének DNS-analízisét DNSszekvenálás vagy genomiális átrendeződést igazoló vizsgálatokkal [22-25]. Ezen vizsgálatok pontos metodikája már közlésre került [26]. Később az igazolt patogén mutációt hordozó betegek családfa-analízisét is elvégezzük, és az érintett alanyokat gondozásba vesszük, ezzel is javítva a szürés és a terápia hatékonyságát.

Azoknál a betegeknél, akiknél igazolódott az MMRgén mutációja, továbbá ezen betegek igazolt mutációt hordozó rokonainál az elkezdett és évente ismételt kolonoszkópia és a szoros utánkövetés szignifikánsan csökkenti a colorectalis daganatok mortalitását (1. táblázat) $[10,11,20,27]$.

Tekintettel arra, hogy a kialakult vastagbélpolipok malignus transzformációja egy-két év alatt bekövetkezik, fontos a sporadikus esetekétől eltérően akár évente vagy kétévente elvégzett vastagbéltükrözés. Különös figyelmet kell fordítani a jobb colonfél áttekintésére, mivel a HNPCC-szindrómánál ez a colonfél gyakrabban érintett [22].

A gyomordaganatok kialakulásának valószínúsége HNPCC-szindrómás betegek esetében életük során körülbelül 5-10\% körüli. Leggyakrabban intestinalis típusú. Gasztroduodenoszkópiát az antrum régiójából vett
1. táblázat |Útmutatás magas kockázatú vagy igazolt HNPCC-s beteg követésére

\begin{tabular}{ll}
\hline Kolonoszkópia & Minden egy-két évben. \\
& 20-25 éves kortól kezdve vagy kettő-öt \\
& évvel korábban, mint a legfiatalabb, \\
& vastagbéldaganattal diagnosztizált vér \\
& szerinti rokon. \\
& MSH6-gén mutációja esetén 30 éves \\
& kortól, PMS3-gén mutációja esetén 35 \\
& éves kortól. \\
\hline Felső panendoszkópia & $\begin{array}{l}\text { Antrumbiopsziával együtt minden } \\
\text { két-három évben. } \\
\text { 30-35 éves kortól. }\end{array}$ \\
\hline Frakcionált küret & Minden évben. \\
& $30-35$ éves kortól. \\
\hline Transvaginalis ultrahang & Minden évben. \\
& $30-35$ éves kortól. \\
\hline Vizeletvizsgálat & Minden évben. \\
& $30-35$ éves kortól. \\
\hline
\end{tabular}

biopsziavétellel egybekötve két-három évente ajánlott elvégezni.

Endometriumcarcinoma esetén a transvaginalis ultrahangvizsgálat specificitása és szenzitivitása önmagában alacsony. Szövettani mintavétel szükséges, amelyet minden évben ajánlatos elvégezni 30-35 éves kortól, CA-125 tumormarker levétele mellett $[22,28]$.

A vizeletelvezeto" rendszer, ezen belül is a tranzicioncelluláris vesekehely- és ureterdaganat kialakulása a HNPCC-szindrómás betegeknél életük során 0,2-25\%os valószínúséggel következik be. Leggyakrabban MSH2-gén-mutáció esetén figyelhetjük meg kialakulását. A vizelet- és ultrahangvizsgálat specificitása és szenzibilitása, sajnos, igen alacsony. Ezeknek a vizsgálatoknak előnye azonban, hogy nem invazívak és olcsók, valamint a rutin urológiai vizsgálat részét képezik. Konszenzus alapján 30-35 éves kortól évente javasolják ezeket elvégezni $[29,30]$.

\section{Eredmények}

\section{Igazolt patogén MMR-gén-mutációval rendelkezö beteg rövid kórtörténete}

Az indexszemély - 44 éves nóbeteg - kivizsgálása székelési habitus megváltozása és fogyás miatt indult el, más intézetben. Ennek során colon descendens tumor igazolódott. 2006. március 30-án bal oldali hemicolectomiát végeztek. Posztoperatív időszakban adjuváns XII. ciklus de Gramont-séma szerinti kemoterápiában részesült. A 2007. február elején készült hasi ultrahangvizsgálat és kolonoszkópia lokális recidíva gyanúját vetette fel. A $35 \mathrm{~cm}$ magasan kifekélyesedő tumoros folyamatból vett szövettani minta alacsonyan differenciált adenocar- 
cinomát igazolt. Klinikánkra ekkor került felvételre, és kezdtük el szűrését HNPCC-szindróma irányába. Betegünknél elvégzett szûrés során a hMSH2 6. exon két bázispárt érintő deletiója (c.969-970delTC) igazolódott, amelyet elsőként közöltünk az irodalomban [26]. Recidív vastagbéltumor miatt elvégzett mütét során kismedencei carcinosist találtunk, Hartmann-típusú vastagbélreszekciót és részleges kismedencei peritonectomiát végeztünk. A beteg négy ciklus folfiri-avastin, majd három ciklus campto-avastin kombinációt kapott. Tumoros folyamatot a hasüregben a 2008-ban elvégzett mütét előtti vizsgálatok és Hartmann-rekonstrukció során nem találtunk. Tekintettel arra, hogy betegünknél igazolódott a HNPCC-szindróma, a sporadikus esetektől eltérően sưrübben történtek kontrollvizsgálatok és kolonoszkópia. Ezek során polipectomia több alkalommal történt, amelynek szövettani eredménye adenomát igazolt. Ezek során így újabb vastagbéldaganat kialakulását már nem tapasztaltuk. Ellentétben a rendszeres kolonoszkópiákkal, a nőgyógyászati vizsgálatok során csak a méhnyakrák irányába történtek rendszeres ellenőrzések. A vastagbélen kívüli HNPCC-re jellemző endometriumdaganat protokoll szerinti rendszeres szűrése nem történt meg. 2013 szeptemberében más intézetben szinkron duplex uterustumor miatt hysterectomia történt, kétoldali petefészek-eltávolítással. Végleges szövettan egyrészt jól differenciált endometriumcarcinomát, másrészt leiomyosarcomát igazolt. Posztoperatív sugárkezelésben részesült. A 2016 márciusában elvégzett kontroll PET-CT a máj VII. szegmentumában egy $10 \mathrm{~mm}$-es szoliter, továbbá egy $15 \mathrm{~mm}$-es retroperitonealis radio- farmakon-dúsulást igazolt. Tekintettel a PET-CT-n észlelt, malignusnak imponáló paraaorticus nyirokcsomómegnagyobbodásra és szoliter májelváltozásra, szövettani diagnózis céljából mútéti mintavétel történt a nyirokcsomó-konglomerátumból. A májban kóros elváltozás nem volt fellelhető. A végleges szövettan a korábbi endometriumcarcinoma áttétét igazolta.

\section{A beteg családfa-analizise és gondozásba vétele}

2007-ben, a beteg klinikánkon történő első észlelésénél, több generációt átölelő családfa-analízist végeztünk, amelynek során kiderült, hogy viszonylag fiatal életkorban vastagbél-, endometriumdaganat és lymphoma is megjelent első-, másod- és harmadrendű rokonoknál. Az indexszemély anyai nagyanyjánál 52 éves életkorban, majd a következő két generációban is vastagbél- és endometriumcarcinoma előfordulását tapasztaltuk fiatal életkorban (1. ábra). Összehasonlítva a két családfát, ki kell emelni, hogy az első felfedezés óta eltelt 10 év alatt betegünknél és rokonainál újabb, a HNPCC-re jellemző metakrón tumorok jelentek meg. Három újabb vastagbéldaganat, két endometriumcarcinoma, egy endometriumban kialakult leiomyosarcoma, egy melanoma és egy központi idegrendszeri daganat megjelenését tapasztaltuk (2. ábra). Az indexszemély húgánál 30 évesen derült fény vastagbéldaganatra, majd 14 év múlva metakrón vastagbéldaganat alakult ki. Ez alatt a 14 év alatt csak az első öt évben járt rendszeres kontrollra. Más intézetben 44 évesen ileus klinikai tüneteivel került felvételre, és sürgős mütétet végeztek. Az indexbeteg édesanyjánál 72

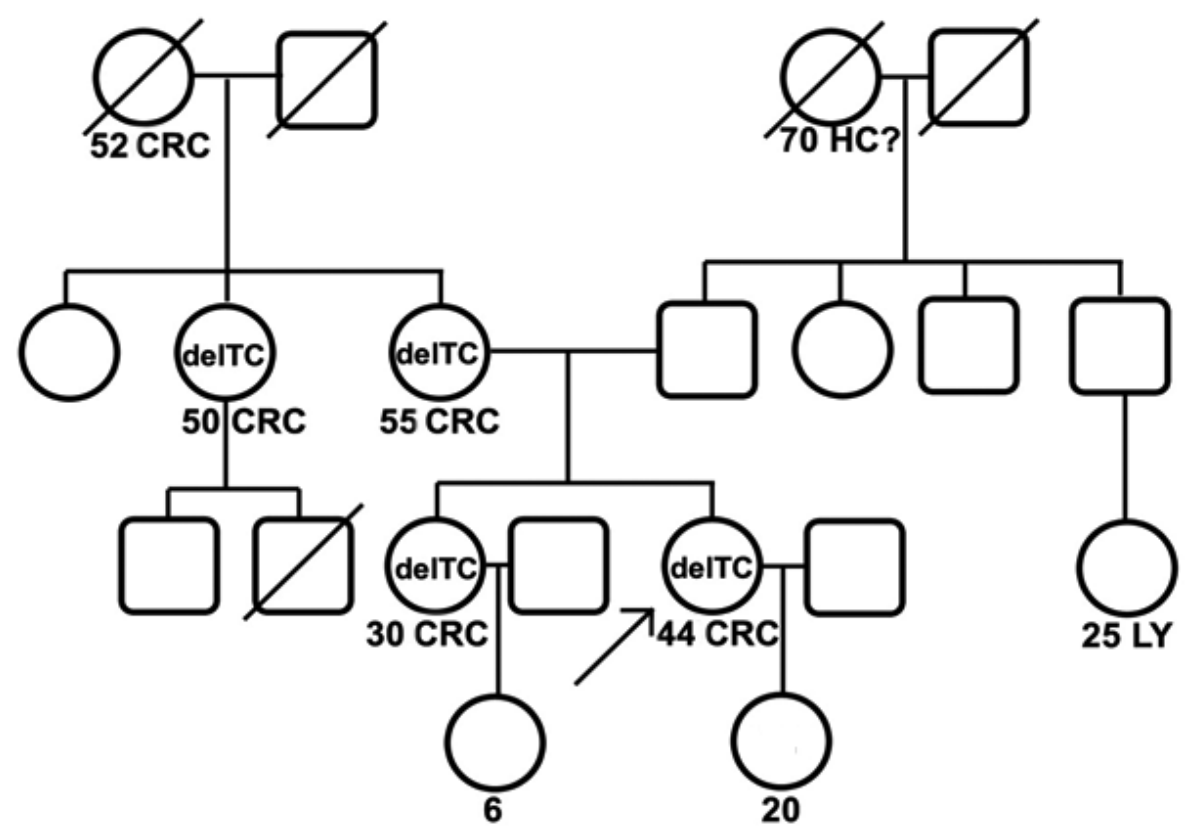

\begin{tabular}{l|l} 
1. ábra & $\begin{array}{l}\text { Igazolt HNPCC-szindrómás betegünk } 10 \text { ével ezelőtti családfája } \\
\text { Indexszemély nyíllal jelölt. } \\
\mathrm{CRC}=\text { colorectalis carcinoma } \mathrm{HC}=\text { hepatocelluralis carcinoma; } \mathrm{LY}=\text { lymphoma }\end{array}$
\end{tabular} 


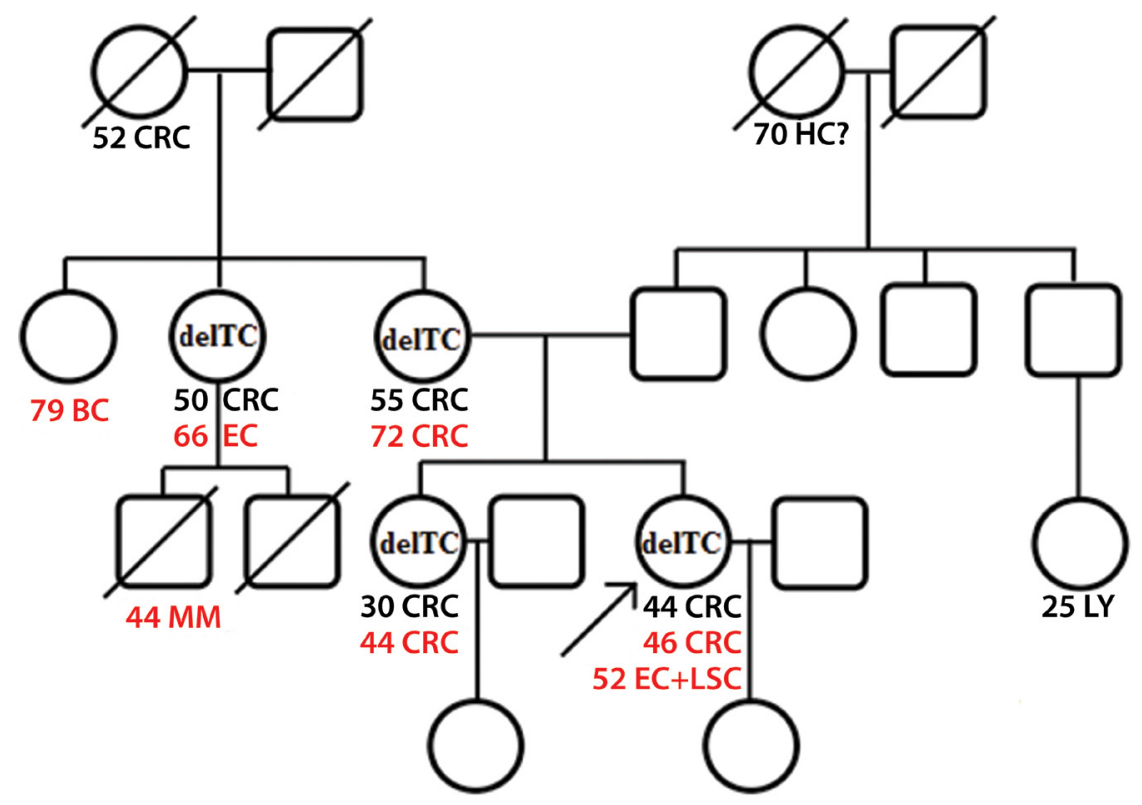

\begin{tabular}{l|l} 
2. ábra & $\begin{array}{l}\text { Igazolt HNPCC-szindrómás betegünk jelenlegi családfája } \\
\text { Az első felfedezés óta eltelt } 10 \text { év alatt betegünknél és rokonainál újabb, a HNPCC-re jellemző metakrón tumorok jelentek meg (pirossal jelölve). } \\
\mathrm{BC}=\text { központi idegrendszeri daganat; CRC = colorectalis carcinoma; EC = endometriumcarcinoma; HC = hepatocellulalis carcinoma; LSC = lei- } \\
\text { omyosarcoma; } \mathrm{LY}=\text { lymphoma; } \mathrm{MM}=\text { melanoma malignum }\end{array}$
\end{tabular}

éves korában, 17 évvel az első eset után diagnosztizáltak metakrón vastagbéldaganatot, nem járt rendszeres kontrollra. Tünetei nem voltak, viszont a családtagok kérésére ment el kolonoszkópiára, miután tudomásukra jutott indexbetegünk öröklődő genetikai szindrómája. Az indexbeteg nagynénjénél 50 éves korában vastagbéldaganat miatt teljes vastagbél-eltávolítás történt. A későbbiekben emiatt kolonoszkópia nem volt indokolt. Endometriumcarcinoma irányába rendszeres nőgyógyászati vizsgálatok nem történtek. 16 év múlva hüvelyi vérzés miatt indult kivizsgálás, és metakrón endometriumdaganat miatt történt histerectomia és posztoperatív sugárkezelés.

\section{Következtetés}

A Lynch-szindrómás betegek és igazolt mutációt hordozó családjuk gondozásba vétele, egy-két évente elvégzett kolonoszkópia, valamint a nőgyógyászati szúrővizsgálatok jelentősen csökkentenék a mortalitást. Mindezek ellenére szưrésük és a gyanús esetek felismerése nem rutinszerü hazánkban. Klinikánkon több éve alapos, több generációra kiterjedő, a HNPCC-ajánlásoknak megfelelő szűrésnek köszönhetően évente több HNPCC-szindrómás beteg kerül látóterünkbe, és vesszük őket, illetve családjukat gondozásba. HNPCC-szindrómás betegünk 10 évvel ezelőtti és jelenlegi családfájának ismertetése ékesen bizonyítja, hogy a szoros utánkövetésnek köszönhetően az együttmúködő betegeknél sikerült korai stádiumban diagnosztizálni az új tumoros megbetegedéseket és metakrón tumorokat.
Anyagi támogatás: A cikk megírása, illetve a kapcsolódó kutatómunka anyagi támogatásban nem részesült.

Szerzôi munkamegosztás: K. G.: A kézirat megszövegezése, adatgyưjités, adatok elemzése, kérdőívek kitöltése, kapcsolattartás. O. J.: MMR-gének mutációinak keresése, DNS-szekvenálás vagy genomiális átrendeződést igazoló vizsgálatok. T. L.: Immunhisztokémiai vizsgálatok elvégzése. U. H.: Szakmai tanácsadás. A. Cs.: Szaktanácsadás. B. T.: Gasztroenterológiai szakvélemény. P. K.: Gasztroenterológiai szakvélemény. D. L.: Szakmai kontroll. T. M.: Szakmai kontroll, eredmények értelmezése. A cikk végleges változatát valamennyi szerző elolvasta és jóváhagyta.

Érdekeltségek: A szerzőknek nincsenek érdekeltségeik.

\section{Irodalom}

[1] Schneikert J, Behrens J. The canonical Wnt signalling pathway and its APC partner in colon cancer development. Gut 2007; 56: $417-425$

[2] Lichtenstein P, Holm NV, Verkasalo PK, et al. Environmental and heritable factors in the causation of cancer-analyses of $\mathrm{co}^{-}$ horts of twins from Sweden, Denmark, and Finland. N Engl J Med. 2000; 343: 78-85.

[3] Peltomaki P, Vasen HF., The International Collaborative Group on HNPCC. Mutations predisposing to hereditary nonpolyposis colorectal cancer: database and results of a collaborative study. Gastroenterology 1997; 113: 1146-1458.

[4] Giardiello FM, Allen Jl, Axilbund JE, et al. Guidelines on genetic evaluation and management of Lynch syndrome: a consensus statement by the US Multi-Society Task Force on Colorectal Cancer. Gatroenterology 2014; 147: 502-526. 
[5] Lynch HT, Smyrk TC, Watson P, et al. Genetics, natural history, tumor spectrum, and pathology of hereditary nonpolyposis colorectal cancer: an updated review. Gastroenterology 1993; 104: $1535-1549$

[6] Marra G, Boland CR. Hereditary nonpolyposis colorectal cancer: the syndrome, the genes and historical perspectives. J Natl Cancer Inst. 1995; 87: 1114-1125.

[7] Van de Wetering M, Sancho E, Verweij C, et al. The $\beta$-catenin/ TCF-4 complex imposes a crypt progenitor phenotype on colorectal cancer cells. Cell 2002; 111: 241-250.

[8] Tamura G. Alterations of tumour suppressor and tumour-related genes in the development and progression of gastric cancer. World J Gastroenterol. 2006; 12: 192-198.

[9] Weinberg RA. Maintenance of genomic integrity and the development of cancer. In: The biology of cancer. Garland Science, Taylor \& Francis Group, LLC, New York and Abingdon, 2007; pp. $463-526$.

[10] Duval A, Hamelin R. Mutations at coding repeat sequences in mismatch repair-deficient human cancers: toward a new concept of target genes for instability. Cancer Res. 2002; 62: 2447-2454.

[11] De la Chapelle A. Microsatellite instability. N Engl J Med. 2003; 349: 209-210.

[12] Eisen JA. Mechanistic basis for microsatellite instability. In Goldstein DB, Schlotterer C. (eds.) Microsatellites: Evolution and applications. Oxford University Press, Oxford, 1999; pp. $34-48$.

[13] Atkin NB. Microsatellite instability. Cytogenet Cell Genet. 2001; 92: 177-181.

[14] Mori Y, Yin J, Rashid A, et al. Instabilotyping: comprehensive identification of frameshift mutations caused by coding region microsatellite instability. Cancer Res. 2001; 61: 6046-6049.

[15] Kovacs ME, Papp J, Szentirmay Z, et al. Deletions removing the last exon of TACSTDI constitute a distinct class of mutations predisposing to Lynch syndrome. Hum Mutat. 2009; 30: $197-$ 203.

[16] Papadopoulos N, Nicolaides NC, Wei YF, et al. Mutation of a 'mutL' homolog in hereditary colon cancer. Science 1994; 263: $1625-1629$

[17] Kempers MJ, Kuiper RP, Ockeloen CW, et al. Risk of colorectal and endometrial cancers in EPCAM deletion-positive Lynch syndrome: a cohort study. Lancet Oncol. 2011; 12: 49-55.

[18] Teutsch SM, Bradley LA, Palomaki GE, et al. The Evaluation of Genomic Applications in Practice and Prevention (EGAPP) initiative: methods of the EGAPP Working Group. Genet Med. 2009: 11: 3-14

[19] Hampel H, Frankel WL, Martin E, et al. Feasibility of screening for Lynch syndrome among patients with colorectal cancer. J Clin Oncol. 2008; 10: 5783-5788.
[20] Watson P, Lynch HT. Extracolonic cancer in hereditary nonpolyposis colorectal cancer. Cancer 1993; 71: 677-685.

[21] Vasen HF, Wijnen JT, Menko FH, et al. Cancer risk in families with hereditary nonpolyposis colorectal cancer diagnosed by mutation analysis. Gastroenterology 1996; 111: 1402.

[22] Giardiello FM, Allen JI, Axilbund JE, et al. Guidelines on genetic evaluation and management of Lynch syndrome: a consensus statement by the US Multi-Society Task Force on Colorectal Cancer. Am J Gastroenterol. 2014; 109: 1159-1179.

[23] González-Aguilera JJ, Nejda N, Fernández FJ, et al. GeneticAL alterations and MSI status in primary, synchronous, and metachronous tumors in a family with hereditary nonpolyposis colorectal cancer (HNPCC). Am J Clin Oncol. 2003; 26: 386391.

[24] Vasen HF, Watson P, Mecklin JP, et al. New clinical criteria for hereditary nonpolyposis colorectal cancer (HNPCC, Lynch syndrome) proposed by the International Collaborative Group on HNPCC. Gastroenterology 1999; 116: 1453-1456.

[25] Cunningham JM, Christensen ER, Tester DJ, et al. Hypermethylation of the hMLHl promoter in colon cancer with microsatellite instability. Cancer Res. 1998; 58: 3455-3460.

[26] Tanyi M, Olasz J, Kámory E, et al. Difficulties in recognizing families with hereditary non-polyposis colorectal carcinoma: Presentation of 4 families with proven mutation. Eur J Surg Oncol. 2008; 34: 1322-1327.

[27] Dove-Edwin I, Sasieni P, Adams J, et al. Prevention of colorectal cancer by colonoscopic surveillance in individuals with a family history of colorectal cancer: 16 year, prospective, follow-up study. BMJ 2005; 331: 1047.

[28] Gerritzen LH, Hoogerbrugge N, Oei AL, et al. Improvement of endometrial biopsy over transvaginal ultrasound alone for endometrial surveillance in women with Lynch syndrome. Fam Cancer 2009; 8: 391-397.

[29] Van der Post RS, Kiemeney LA, Ligtenberg MJ, et al. Risk of urothelial bladder cancer in Lynch syndrome is increased, in particular among MSH2 mutation carriers. J Med Genet. 2010; 47: 464-470.

[30] Myrhøj T, Andersen MB, Bernstein I. Screening for urinary tract cancer with urine cytology in Lynch syndrome and familial colorectal cancer. Fam Cancer 2008; 7: 3003-3007.

(Kóder Gergely dr., Debrecen, Móricz Zsigmond krt. 22., 4032 e-mail: gregk@freemail.hu)

\section{Tisztelt Szerzőink, Olvasóink!}

Az Orvosi Hetilapban megjelenő/megjelent közlemények elérhetőségére több lehetőség kínálkozik.

Rendelhetö különlenyomat, melynek áráról bövebben a www.akkrt.hu honlapon (Folyóirat Szerzöknek, Különlenyomat menüpont alatt) vagy Szerkesztöségünkben tájékozódhatnak.

A közlemények megvásárolhatók pdf-formátumban is, illetve igényelhetö Optional Open Article (www.oopenart.com).

Adott dij ellenében az online közlemények bárki számára hozzáférhetök honlapunkon (a közlemények külön linket kapnak, igy más oldalról is linkelhetővé válnak).

Bővebb információ a hirdetes@akkrt.hu címen vagy különlenyomat rendelése esetén a Szerkesztőségtől kérhető. 